\title{
Using Theory To Tell It Like It Is
}

\author{
Stephanie J. Waterman
}

Published online: 27 February 2013

(C) Springer Science+Business Media New York 2013

\begin{abstract}
In this article a graduate level diversity course, "Diversity \& Equity in Higher Education" that is based on Johnson's (2005) Privilege, Power, and Difference, and Critical Race Theory (CRT) (Tate in Rev Res Educ 22:195-247, 1997) is described. Johnson's concepts, such as paths of least resistance, are explained, as well as CRT, and forms of multiculturalism. The course format, the instructor's philosophy toward this course, and course assignments are shared. Using the CRT analysis tool developed by former students of this course, an example from a student's paper is provided as an example of how to use the tool, and how theory is used to help students "see" injustice and oppression. Challenges, such as tackling a complex topic in one semester, are discussed and recommendations are made, such extending the course for two semesters.
\end{abstract}

Keywords Privilege - Critical Race Theory · Higher education · Diversity

We need to find practical application for these theories (Anzaldúa 1990, p. Xxvi)

I have been teaching a diversity course in higher education since 2003 and have found that students are reluctant to label an event or act as "racist" even when the situation has nothing at all to do with the students personally. While no one wants to

Dr. Waterman's research interests are Native American college experiences, the role staff play in student retention, race and gender in higher education, Indigenous methodologies/epistemologies, college transition, and critical race theories. She has taught Diversity \& Equity in Higher Education, History of Higher Education, History of American Education, College Student Development Theory, and Qualitative Research Methods.

S. J. Waterman $(\bowtie)$

Warner Graduate School of Education and Human Development, University of Rochester,

P.O. Box 270425, Rochester, NY 14627, USA

e-mail: swaterman@warner.rochester.edu 
be called a racist, and my goal is not to have students label everyone and every joke, slight, or insult as racist, it is important for students to recognize racism and social injustice. I introduce the class to Johnson's (2005) Privilege, Power and Difference, and then use Critical Race Theory (CRT) (Ladson-Billings 1998; Tate 1997) as the theoretical foundation of my course. Johnson's work is accessible and addresses systems of privilege in a way that enables students to remain open rather than defensive. Once students increase their social justice awareness using the Johnson text, CRT provides the core theory we use to critically analyze and address seemingly normal day-to-day experiences. Using critical theory, students are able to say, "Through a CRT lens, the event was racist." Once able to "tell it like it is" through the theory, students are able to think in more nuanced ways about oppression and injustice.

I agree with Kumashiro (2000) that it is crucial to go beyond empathy, and "learning about others," because what society defines as 'normal' is narrowly defined and based on the experience of White, heterosexual males (p. 31). Learning about others, our differences as well as similarities, only maintains a dichotomy as well as locating the "problem" with the "other." Hidden assumptions and stereotypes that drive our lives (such as narrowly defined ways to be a man) are not interrogated because they have become social norms. By not interrogating these hidden assumptions, the status quo is maintained, and we all suffer because many of these assumptions are stereotypes based on oppression or racism. Johnson challenges us to:

Consider the damage men often do to themselves and one another in trying to measure up as 'real men,' how they limit their humanity, deny their needs, don't ask for help, and often live with chronic fear, anxiety, isolation, and loneliness. (p. 60)

Regarding race and racism, one does not have to behave in an overtly racist manner or participate in racist organizations; by not discussing the ways in which race impacts the systems in which we engage, racism is maintained (Bonilla-Silva 2003) without any real conscious thought (Johnson 2005). Kumashiro's (2000) discussion of anti-oppressive education is useful here, as he encourages us to go beyond "consciousness-raising," because "reason and reason alone" are not enough to challenge oppression (p. 39). This is why learning about others has not helped us move to a socially just society. It is difficult to challenge what we already know, what we may have learned in school, or heard from authorities. "Anti-oppressive education, then, needs to involve overcoming this resistance to change and learning, instead, to desire change, to desire difference" (p. 43). The course described in this article aims to involve "different knowledges" to challenge the "harmful" ones that dominate the landscape (p. 44).

In this article I describe a diversity course at the graduate level in a higher education program. Theory is put to use to aid students in their awareness of race and social justice issues. While I find that this course format and theoretical framework works well, it is not the only way. I offer my thoughts to inform critical theorists, those looking for practical uses of theory, and instructors of diversity/ social justice issues. This article will introduce the theoretical underpinnings of the 
course beginning with the commonly employed multicultural concepts. The organization of the course and nature of assignments will then be explained. An example of a student's assignment will be shared, followed by a discussion section, and then challenges regarding the course. First, a comment about the methodological approach of this article follows.

Qualitative document analysis (Bogdan and Biklen 2007) of student work and academic texts form the basis of this article. As critical theory informs this course, counter-stories (described in detail below) as defined by CRT drives my approach to this article. Thus, storytelling is central to this article; this is my experience, and the student example an expression of the student's experience employing CRT in her book content analysis. CRT supports many purposes of storytelling such as "counter[ing] stories of the oppressor" (Tate 1997, p. 220) and in community building. CRT, importantly, legitimates story as a mechanism to understand the role of race and gender in America. Story not only instructs, stories "can lead readers to patterns or associations in their own experience, combined with which they will generate their own unique meanings" (Cleary and Peacock 1997). My experience teaching the course for several years also informs, as well as my informal conversation with other instructors of diversity and with other women of color who teach in predominantly White environments. As a woman of color, teaching this course, I am the expert of that experience (Collins 1995).

\section{Diversity/Multicultural Frameworks}

Multiculturalism is a concept with which many students are familiar and comfortable. In the first class we discuss, and begin to interrogate, forms of multiculturalism. In teacher education there are three main approaches to diversity: culturally relevant pedagogy (Howard 2003; Ladson-Billings 1995; Sleeter 1993); multicultural education (Banks and Banks 2001; Grant and Tate 2001); and critical theories such as Critical Race Theory (Ladson-Billings 1998) that are also applied to higher education. At the post-secondary level, Rhoads $(1995,1998)$ identifies three types of multiculturalism: conservative multiculturalism, mainstream multiculturalism, and critical multiculturalism.

Conservative multiculturalism preserves the established canon and supplements them with diverse course offerings. Diversity becomes a topic of study, a study of others. Kumashiro (2000) might call this "the rationalist approach to consciousnessraising" (p. 39). While mainstream multiculturalism also centers on learning about others by adding courses to an established canon, this second approach considers different perspectives and viewpoints as "relevant" aiming to produce students who are more "familiar and accepting of diverse cultures" (Rhoads, p. 40, 1998). This is also referred to as the "human relations" (p. 40) approach, the "we-can-all-getalong if we know more about each other" approach. Both conservative and mainstream multiculturalism aim for intergroup tolerance without challenging the established canon, social structure, or addressing issues of power. Marginalized 
groups and ethnic studies programs or support services remain marginalized as a result.

In response to the above efforts toward "tolerance" as opposed to approaches that could produce social change, Bensimon (1994) suggests a third approach, critical multiculturalism.

A transformative version of multiculturalism ... combines conditions of cultural diversity with the emancipatory vision of critical educational practice borrowing from postmodernism, critical theory, and feminism. This form of multiculturalism seeks to transform the academy from monolithic centers of power to democratic constellations in which organizational structures reflect a multiplicity of perspectives. (Rhoads \& Solorzano, 1995 in Rhoads 1998, p. 41)

A critical multicultural approach moves beyond adding a diversity course. In this third approach university practices are questioned. For instance, pedagogical practices, admissions policies, hiring practices, and organizational structures are considered from the perspective of diversity. This approach aims to change practices; otherwise the status quo is maintained. In his discussion of curriculum Rhoads (1995) gives the example of "renovating a house by painting it, but doing nothing to alter the underlying framework and foundation" (p. 270). Conservative and mainstream multiculturalism are painting the house-not refurbishing the house.

As a critical theory, critical multiculturalism calls for change, change in the structure of postsecondary institutions that privilege a certain culture and social class. CRT, as will be explained in the next section, calls for an end to oppression and racism. Critical multiculturalism fits nicely with CRT. I use critical multiculturalism, however, students need tools to see the structure before they can change it. The next section outlines the theories used in the course that help students become aware of race and social injustice.

\section{Theoretical Frameworks}

\section{Johnson, Privilege, Power, and Difference}

Johnson (2005) is an accessible work on systems and privilege in our society that have to do with social class, race, ability status, and gender. Johnson places us all in this invisible system of oppression but does so in a way that seems to interrupt students' assumptions without making them defensive. Students come to see social injustice and oppression in commonplace places and situations-and are often surprised by what they find. For others, Johnson provides validation that their suspicions were valid. For instance, a White student might become aware that her ability to always find an apartment and always get a job may have had something to do with her race as she observes that every one of her landlords and employers have been White, and a Black student indicated she felt relief and affirmation to learn that, indeed, there is a system based on privilege and language to describe it. 
Johnson (2005) begins by naming race and privilege. Once we name something, it becomes difficult to ignore. Because we do not talk about or name privilege, heterosexism, and racism, for instance, we can avoid any selfreflection, such as "how does heterosexism work for me?" (p. 9). Johnson complicates labels by showing students how labels work to exploit difference. Once privilege and the other "isms" are named, Johnson walks us through the social construction of race and difference and the fear mongering and competitiveness inherent in a capitalistic industrial society that values individualistic motivation and drive. Because we participate in this invisible system, we are all complicit in the system (Johnson 2005). A particularly accessible concept for students is what Johnson calls "paths of least resistance" (p. 80). During our day we have "almost a limitless number of choices" (p. 80) regarding our behavior; however, we are typically not aware of those choices. A simple example Johnson provides is behavior in an elevator. We could face the wall of the elevator, with our back to the door, but very quickly we would know that we were violating a "social norm" (p. 80). We follow paths of least resistance because they are easy, especially when resisting means speaking up or going against social norms. An example of complicity in the system is continuing to hire from the same pool of people, without seeking a wider pool of candidates. Going along with a sexist or ethnic joke is another example. Ways to fight the system, to resist the path of least resistance, are to cast a wider net for potential job candidates, confront sexist/racist/LGBTQ jokes, and bring attention to injustice-in other words, not remain silent and maintain the status quo. Johnson (2005) also discusses the cost of privilege such as maleness, and the narrow definition of "masculinity" which discourages emotion and tenderness. For all students, Johnson (2005) is a starting point, providing a common vocabulary. Having built awareness of the systems of privilege and power, the class moves on to Critical Race Theory.

\section{Critical Race Theory}

DeCuir and Dixson (2004) argue that because racism is so subtle in our lives, Critical Race Theory is a useful tool "to examine the experiences of AfricanAmerican students" (p. 26) through examples of additional CRT foundations such as Whiteness as property, interest convergence, and CRT's usefulness as a critique of liberalism. The tenets of CRT provide a point-by-point framework from which to interrogate the subtle racism in our lives.

In this class, I assign Tate's (1997), Critical Race Theory and Education: History, Theory, and Implications chapter from the Review of Research in Education to provide a comprehensive introduction to the theory. I want to establish the seriousness and complexity of race and critical theory early in the course. Yosso's (2006) Critical Race Counterstories along the Chicana/Chicano Educational Pipeline is assigned to provide an application of this theory and as the Latino/a focused content for the course.

Critical Race Theory grew out of scholars' frustration with slow legal civil rights' recourse (Bell 1987; Crenshaw 1988). A legal approach to civil rights 
issues operates within a "legal ideology" or framework, thereby limiting effectiveness in enacting social justice change, "help[ing] construct, maintain, and legitimate America's present class structure" (Tate 1997, p. 229). CRT focuses on race in an analysis of systems, events, legal decisions, etc. and employs epistemological approaches as necessary to grapple with complex concepts going beyond one discipline or dimension. For example, Native American educational attainment lags behind other populations in the United States (Aud et al. 2011). To investigate the reasons for this achievement gap, one has to look beyond the school to federal relocation policies, local economies, teacher education programs, the role of churches, and transportation to name some areas of inquiry.

Objectivity, meritocracy, and other dominant ideologies are exposed as masks for the self-interest of the dominant group (Tate 1997, p. 235). A CRT theorist interrogates the meaning and implications of color-blind policies. High school graduation dress code policies that restrict regalia to specific colors with no adornment to the cap and gown are color-blind policies because they represent an expression of one culture, silencing representation from other cultures (Martinez 2006; DeCuir and Dixson 2004). Because the history of oppressed groups has been silenced by the dominant society, CRT re-introduces the history and experiences of oppressed groups through counterstory, described next.

Counterstory-telling is an important element of CRT (Tate 1997). Counterstories reveal the lived experiences of non-dominant groups that are typically not acknowledged by the dominant society. The popular notion that the victor writes the history is the common person's understanding (this quote is often attributed to Winston Churchill) that not all stories are told. CRT insists that those stories be told. Yosso's (2006) narrative is an example of counterstory-the story of Latino/a educational experiences as told by Latino/as.

Interest convergence is another important element of CRT. Tate demonstrates that change happens most often for oppressed groups when the interests of the dominant group are aligned with those of the oppressed group. An example is when the state of Arizona resisted the establishment of the Martin Luther King Jr. holiday. The National Basketball Association and National Football League both indicated that they would not play championship games in that state. After this threat, interests "converged"-Arizona desired the potential revenue from professional playoff games and came to realize the benefit of establishing the Martin Luther King, Jr. holiday-Arizona's decision was reversed (LadsonBillings 1998, p. 12).

All teachers operate from a set of understandings that guide their practice, supporting their choice of teaching methods and classroom interaction. A course like the one I am describing challenges the instructor to be clear about her choices and the reasons for them. My philosophy regarding this course is reflected in the pedagogy I employ. While modeling and facilitating, rather than explicit lecture, are common in my teaching, I believe this course requires even more facilitation. I explain below. 


\section{Instructor Philosophy}

Self-description, establishing trust through self-disclosure, leading students to see injustice, and my assessment of where students are intellectually are central features of my pedagogy. Because I require a self-description-a short autobiography-I model the self-description in class by introducing myself. I mention the areas in which I am privileged (a female who can legally marry in all states), and areas I may not be privileged (female in a largely male profession). I introduce my many roles: mother, wife, grandmother, educator, member of a small community suddenly thrust into a large city, one of two Native faculty at the institution, etc. I share the economic conditions I experienced as a child and the extended family that lived in our home. I mention the languages spoken in our home, and my grandparents' experience with the Native American boarding school and its multi-generational legacy. In addition to sparking self-awareness, I assign a self-description at the beginning of the course, because I need to know if a student has had particular experiences that I need to be aware of. For the vast majority of the students I have taught, I am the first Native American they have ever met, and so far, for all, their first Native American instructor. I model selfreflection because that is what I expect the students to share in their journals. I once teased one of my students when I was in her building and saw her emptying her trash along with the custodian. I felt terrible afterward because I had devalued the work of the custodian-whose work I acknowledge every day. Experiences such as this, even though embarrassing or upsetting, allow me to model what I expect students to do and encourages trust because they see that I, too, make mistakes.

Trust must be established early in the class. My syllabus includes the policy that racist or hurtful remarks will require a public apology, and so far none has been required. I allow space for reflection and talk-literally. Sometimes the room is quiet as I let students think before they speak. I also do not want to be responsible for interpreting or analyzing; I feel silence encourages the students to work their analysis through as a class. Students will offer their thoughts or interpretation and work off each other; the students come to direct that talk, and I let it happen.

There is an old adage that you can lead a horse to water, but you can't make the horse drink that undergirds my teaching philosophy. My philosophy is that I can lead students to the water, but if they cannot see the water, they cannot drink the water. I use Johnson's "paths of least resistance" and CRT as tools to uncover systems of privilege and racism that are commonplace in the dominant society. In this sense, the water is the system-a system laced with privilege, oppression, and racism. I believe we construct knowledge together (Vygotsky 1986). I firmly believe that we learn socially and experientially from each other, from what we see, from what we talk about, and what we do not talk about. But I also feel that only showing, telling, and having students read about issues they are not trained to see will not produce socially aware individuals.

I teach graduate students in higher education, the vast majority of whom are practitioners or full-time graduate students who have had experience working in 
student affairs or higher education administration. Few of my students come directly from undergraduate programs. My assumption is that these students are at a level of maturity to embrace new ways of seeing the world and that they are well past dualistic thinking in which students exhibit dichotomous thinking-there is a right answer and typically an authority figure who knows the answer (Love and Guthrie 1999). I make the assumption that students have moved through Perry's Multiplicity positions, in which students begin to value all opinions, to Relativistic thinking in which students realize there are no absolutes, and seek structure in their efforts to evaluate situations (Love and Guthrie). While this developmental trajectory is not accurate for every student, and I question the generalization of these models, the majority of the class is ready to embrace the context of the larger system of oppression in which we all participate, and these students typically help those who are not ready to embrace gray areas and to question authority (Love \& Guthrie).

The dominant society operates on the assumption that we do not question-that we do not "see" the system of oppression (Johnson 2005). Hence, my emphasis is on observation using the specific tenets of CRT to tease out racial and social justice issues in every day life. Theory makes this analysis less personal; students can say the theorist would see a situation in a certain way until they are ready to make it personal. My 2008 spring semester class developed a CRT analysis tool for their class presentations using terminology taken directly from Tate (1997). They applied the tool in a discussion of CRT in response to a film shown in class (see "Appendix 1"). I have since modified the tool to use in my class and at two conference presentations (see "Appendix 2"). The analysis sheet has the five tenets of CRT in a lined table with space provided for an example of each tenet. This tool is useful as a fill-in-the-blank form for analysis - a way to begin the discussion.

\section{Course Format}

The 14-week graduate level course in higher education, Diversity \& Equity in Higher Education, is required for our student affairs concentration, Master's in Health Professions Education, and an elective for others. Students from across the school of education have enrolled in the course, mostly from counseling, and at my former institution, two assistant professors enrolled in the course for creditone from the history department and the other from the school of visual arts. The course is intentionally offered in the spring semester so that we can take advantage of Black History Month and the campus and community events that occur.

The entire class reads Tate (1997) and Yosso (2006), two articles about critical multiculturalism by Rhoads (1995, 1998), and Responding to the Realities of Race on Campus by Harper and Patton (2007). The class is divided into four groups based on a content focus area: the experiences of African American, Asian American, LGBTQ, and Native American college students. These four content areas represent the major student groups present on campus, but Latino/a students are not discussed separately. Yosso's book is discussed throughout the semester, and we focus on the 
ways in which social class and gender intersect these broad content areas. We also complicate the groups by discussing the diversity present within groups, such as broadening the Asian American discussion beyond Chinese and Japanese students. To provide content for these areas, each group focuses on a book that they then use as the basis from which to present their content to the class. One entire class is devoted to the book content, and students take responsibility for leading the class. The books have changed over time. I am open to new material, and because this is a higher education course, the books have an emphasis on student experiences and student services. Table 1 below lists the books used in the spring 2011 semester.

Counterstories are shared through guest speakers and films. We also attend the campus-wide Martin Luther King, Jr. commemorative lecture as a class because these lectures are also counterstories. Past commemorative lectures have included poet Nikki Giovanni and activist The Reverend Dr. Joseph Lowery. Guest speakers to the class have included a White male who was a welfare recipient as a child, a Nation of Islam representative, a Native American professor who researches mascot issues, and a representative from the city's Islamic Center. If a student cannot attend the Martin Luther King, Jr. lecture (it is held on a different night than class) students must attend a lecture or discussion on a diverse topic. I emphasize that the "diverse topic" should be something they are not. For example, if a student identifies as straight, attending a campus drag show qualifies as diverse. Two such lectures have been Thomas Norman DeWolf who wrote Inheriting the Trade: A Northern Family Confronts Its Legacy as the Largest Slave-Trading Dynasty in U.S. History, and one by Sally Roesch Wagner who wrote Sisters in Spirit: Haudenosaunee (Iroquois) Influence on Early American Feminists. Students who attend these counterstory experiences must then share their observations, perceptions, and reactions with the class and write a reflection paper relating the counterstory in their own words. Events do not have to occur on the institution's campus; attending community and neighboring campus events is encouraged. It is through the repetitive discussion and analysis of these counterstories that students come to see privilege and oppression.

Table 1 Books for content area

\begin{tabular}{|c|c|c|c|}
\hline African American & Asian American & LGBTQ & Native American \\
\hline $\begin{array}{l}\text { Banks, C. A. (2009). } \\
\text { Black women } \\
\text { undergraduates, } \\
\text { cultural capital, and } \\
\text { college success. NY, } \\
\text { NY: Peter Lang. }\end{array}$ & $\begin{array}{l}\text { McEwen, M. K., } \\
\text { Kodama, Alvarez, A. } \\
\text { N., Lee, S. \& Liang, } \\
\text { C. T. H. (Eds.). } \\
\text { (2002). Working with } \\
\text { Asian American } \\
\text { College Students. New } \\
\text { Directions for Student } \\
\text { Services. No. 97, San } \\
\text { Francisco, CA: Jossey- } \\
\text { Bass. }\end{array}$ & $\begin{array}{l}\text { Sanlo, R. (Ed.). } \\
\text { (2005). Gender } \\
\text { Identity and Sexual } \\
\text { Orientation: } \\
\text { Research Policy, and } \\
\text { Personal } \\
\text { Perspectives. New } \\
\text { Directions for } \\
\text { Student Services, } \\
\text { No. 111. San } \\
\text { Francisco, CA: } \\
\text { Jossey-Bass. }\end{array}$ & $\begin{array}{l}\text { Fox, M. J. T., Lowe, S. } \\
\text { C., \& McClellan, G. S. } \\
\text { (Eds.). (2005). Serving } \\
\text { Native American } \\
\text { Students. New } \\
\text { Directions for Student } \\
\text { Services. San } \\
\text { Francisco, CA: Jossey- } \\
\text { Bass. }\end{array}$ \\
\hline
\end{tabular}


Other written assignments include a semester long journal in which students practice applying CRT to every day situations including television shows they may watch. I share that as a NFL football fan, I find it difficult to watch the commercials during games because of the way gender, especially, is presented. I have also shared my conflict over the violence inherent in the game. In addition to the outside lecture reflection, which students often call their "field trip," and the self-description, they must apply CRT and Johnson's (2005) framework to their journal, and write a short paper applying theory to their book content. Their final journal entry is a CRT analysis of their personal journal, and through a Critical Multiculturalism lens (Rhoads 1998), they suggest a way to transform their experience.

I believe that students need to take ownership of the material, and the best way I know to help them do this is to have them lead the class. This strategy has been very successful. I always learn something new. It is especially informative to see the content from their perspective. I am typically impressed by their thoughtfulness in organizing the class. My participation when a group leads the class varies. Some groups include me in activities, while other groups treat me as an observer. Since this is their class, I make every attempt to not speak, although sometimes I have information they need. I have been called on to perform certain roles during group presentations. In one class I was given a script with questions and ways to react to certain parts of their presentation. The group leaders reacted to me in various ways to exhibit different ways of working with students. In another class I was asked to pick a group to join and then asked to share my conflict in choosing the group. As the instructor, and the one with the most power in the room, I reflected that I felt the conflict of showing favoritism, and because of my inherent power, perhaps influencing group dynamics once I joined the group.

\section{How the Analysis Tool Works}

The analysis tool is available to students to guide their CRT analysis. As described earlier, the tool is a table with five CRT tenets with space provided to "fill in the blank." To provide an example of how the class can use the CRT analysis tool to analyze the experience of non-dominant students, excerpts from the content area paper of a student in the Black Women Undergraduates: Cultural Capital, and College Success book group follows. Permission to share portions of the paper was obtained from the student. Banks' (2009) book is about how Black women use social and cultural capital to navigate higher education. The student's paper began with an introduction to CRT and its relation to larger societal systems, before she addressed each tenet of CRT. The student author of this paper was able to see, and express, the ways in which race operates in the United States. In each of the boxes that follow the student points out a tenet of Critical Race Theory, my summary of the student's example appears below each. 
Racism is Endemic to Society

The narrative shared by RGB, a participant in the study..., demonstrated how her personal experience was shaped by race and racism. In describing her experience with the instructor and curriculum of her Fine Arts course, she demonstrated that race-and racism - are constant factors in her student experience. For example, she was asked to speak on behalf of all other black students despite the fact that she did not share a class or any obvious interaction with them ... Banks (2009) explains:

As a black undergraduate woman, [RGB] cannot just go to school and be a student. The positioning of her race, class, and gender on a predominantly white campus...means that she will always be a representative of her race on campus. RGB understood why this particular gaze occurred and tied it to racism (p. 69).

That RGB's identity and experience as a student is constantly tied to and framed by race demonstrates the embeddedness of race within society. Furthermore, the burden of the gaze she carries is not one that is shared by members of other social locations; in fact, she wondered if the professor would have asked White students to speak on behalf of others if they were noticeably struggling in class.

In this example, the student fills in examples of racism that were woven into the fabric of the college education setting of Banks' book. The student notes that RGB's experience is consistently tied to race, examples of the embeddedness of racism.

Expresses Skepticism Toward Dominant Claims of Neutrality, Objectivity, Color Blindness, and Meritocracy

Through these narratives, Banks (2009) challenges the dominant rhetoric of sameness and colorblindness. First, Banks (2009) argues that the experience of transitioning to college is "inherently oppressive for black women undergraduates [who] cannot just be students" (p. 37) due to the "additional, constant, college work of seeking support from students and faculty who understand their position as raced, classed, and gendered beings" (p. 37). This insight criticizes the assumption that all students have the same experiences in college, or that the college environment is neutral and/or requires the same from all students. Certainly RGB's experience in Fine Arts was anything but neutral or common to others as she was singled out on the basis of her racial identity... RGB's experience in Fine Arts also serves as example of colorblindness, as the professor dismissed her suggestion to include art from Africa and black America in class as being simply a current debate in the art world rather than a specific example of silencing and excluding students in class.

In the preceding example, the students' insight is particularly keen in recognizing that the system, in this case higher education, does not treat all students the same, nor is it objective or colorblind. The example referenced in the book is about RGB being asked to speak for all Black students and the instructor's dismissal of the 
counterstory-inclusion of African and Black art in an art class. While this is another example of the embeddedness of racism, in order for the instructor to dismiss Black art and make the RGB speak for all Blacks, and making explicit the non-neutral nature of her place in the class, the instructor had to be aware of her race.

\section{Challenges Ahistoricism and Insists on a Contextual/Historical Analysis} of Institutional Policies

These assumptions can be particularly insidious in their perpetuation of deficit models of students of color (that failures are due to individual or cultural deficiencies, rather than the failure of the system to properly identify and support the needs of all students). In other words, the assumption is that students, not the institution, need to change. RGB pointed out this discrepancy by challenging her professor to realize that the "problem" was the curriculum and mindset of the professor of Fine Arts, not with black students in class (see lines 25-27, Appendix).

Banks (2009) offers a critique of these assumptions, pointing out that they fail to acknowledge the specific historical, cultural, and social factors that have shaped the experience of students of color-particularly black undergraduate women-in a way that differentiates them from their white classmates. She explains:

A common thread that runs through [these narratives] is the idea that historical and social inequalities related to race, class, and gender create conditions that require specific navigation strategies for black undergraduate women (Banks 2009, p. 35).

With this, Banks (2009) recognizes that several specific contextual factors need to be accounted for to truly understand and support the experiences of black undergraduate women. Such legacies include racism, questions about belonging, and membership (Banks 2009, p. 43).

In this example, we see the student's recognition of the historical contexts that learners bring to their educational experiences as well as institutional contexts such as deficit ideologies that impact student experiences. She is able to see that the institution and its curriculum "perpetuate ... social inequalities" (Yosso et al. 2009, p. 660).

Insists on Recognizing the Experiential Knowledge of People of Color and Our Communities of Origin in Analyzing Society

These narratives [of the women] have immense power in identifying-in their own terms - the resources that Black women undergraduates develop and employ to navigate systems of higher education, social and academic relationships therein, and therefore provide a compelling counterexample for the persistent models of deficit thinking. Though black women undergraduates have long been "at the center of debates about higher education and race and class" (Banks 2009, p. 26), these debates have historically overlooked the many forms of cultural capital they create and employ (including social networks, 
family connections, negotiating resources). What emerges from Critical Race Theory (Tate 1997) in general and the work of Banks (2009) in particular is "a new rubric that is more authentic to and reflective of" the undergraduate experiences of black women (Banks 2009, p. 26).

In the preceding example, the student challenges deficit thinking by revealing the cultural capital Black female undergraduates bring with them to college. The complex abilities of these students are often ignored and invisible in the academy.

\section{Is Interdisciplinary and Crosses Epistemological and Methodological}

Boundaries

[R]ecognizing the capital, knowledge, and work of black women undergraduates requires us to cross epistemological boundaries and go beyond our "traditional" understanding of what is required for academic success in college. Banks (2009) explains:

Black women undergraduates must engage in work beyond traditional academic endeavors to ensure college success...most often, their tasks involved resisting and navigating the oppressive material consequences that result as these social locations collide with racist, classist, and sexist societal norms (p. 141).

Therefore, as is evident in RGB's experience, to evaluate the work and success of black women undergraduates solely by grades or homework assignments would be to render invisible - and therefore devalue - a great deal of work they do to ensure their success on campus and beyond.

In the student's entry for the final CRT tenet, she clearly states that by evaluating students solely on grades-in one way-devalues the many complicated tasks involved in college success for Black undergraduate women. The women in the book employed many skills to obtain their college degrees yet grade point averages and retention are typical methods of measuring success.

In the concrete example above of the CRT analysis tool, the student points out that race defines the college experience of the student in the book. CRT asks us to interrogate meritocracy, neutrality, objectivity, and colorblindness. In the example the student points out that RGB's experience "was anything but neutral or common" when asked to speak for all Blacks. She also challenges neutrality in that African American art was not included in the course and the suggestion to do so was dismissed exposing the subjectivity of the curriculum and the instructor. The student's analysis points out that Black students struggling in the art class could be an institutional problem, and not solely a problem of the students; a challenge to institutional policy in the form of curriculum. The exclusion of African works in the art class erases non-dominant contributions and marginalizes them to areas of "other." The student acknowledges the cultural capital present in the Black community, questions why such assets and contributions are overlooked in higher education, and argues that by measuring success in only one way, 
grades, renders invisible the complex navigational skills Black women bring to the academy.

I find CRT is useful to see oppression for other groups as well, and is helpful in investigating the experiences of LGBTQ students. For example, while LGBTQ students are not a race, they are othered and oppressed, their identity as LGBTQ being labeled deviant. LGBTQ students are diverse with intersecting characteristics of race, sex, and class. Civil Rights law has failed this group as LGBTQ rights are still contested in many areas of the United States. Objectivity and neutrality serve dominant interests as seen in policies such as sex-based residence halls and forced sex choices on applications. LGBTQ history, struggles, and successes are largely absent from the curriculum. While many "ethnic" groups are included in student centers, few formally include LGBTQ students.

By completing the CRT analysis tool, students are forced to think of examples of CRT in their every day lives and the topics they research for class. A short discussion of the course follows.

\section{Discussion}

Events throughout the years have been useful for in-class CRT analysis. For instance, the N-word was heard in the institution's hallways with a poor administrative response. Five weeks after the incident an email from administration addressed the issue after a faculty meeting where outrage over the incident was expressed. The email also closed with a quote described as, "Traditional Native American Teaching", with no attribution to which of the over 500 federally recognized Native American tribes this teaching originated. I asked the class, "Was the event and/or response racist?" Although some students were very angry at the incident and the delayed response, most of the class was reluctant to say it was problematic until the CRT analysis tool was used in class during discussion. Another time a guest speaker expressed his religion's view of homosexuality as deviant. This same speaker also expressed his opinion that the primary role for men and women was to be parents. Students were able to critically consider these views using CRT to discuss institutional influences that may have influenced the speaker's opinions. We discussed the narrowly defined role of women as wives, and how that role limits employment, education, and reproductive choice.

When I first began teaching this course, I did not use Johnson (2005). I began with a more qualitative research approach using readings, detailed observations, discussions, and counterstory. But I found that students were having difficulty recognizing their privilege. In their journals students were not able to see how they were connected to a system. Students were also having difficulty with parents and family. Many students shared with me that they were uncomfortable talking with their father (or uncle or some family member) because they felt the family member was a bigot. Students were upset. So was I. This was not what I wanted to happen. Because Johnson spells out the system in which we all participate in an 
easy to understand way, students were able to use Johnson's language and examples when speaking with family. The very first semester that I assigned Johnson, a male student told me his grandmother was reading it with him. Since then I have had several students tell me a family member was reading the book after the semester ended.

Johnson (2005) exposes the exploitation of the system, how capitalism encourages social injustice, and how the status quo relies on oppression, and this approach seems to help students work toward self-reflection. I think many students fear being called a racist-this includes students of color-and focusing on the system eases students into self-reflection of their role in the system, and how their silence maintains an oppressive status quo. There is always the danger that a student is not ready for self-reflection or that a particular student is not aware of his or her race. These students tend to express their beliefs and rationalizations in their journals. The journals are completely confidential, and I erase them after the semester is complete.

\section{Challenges}

The journals can be heartbreaking at times and make me very angry at other times. I have to be very controlled and diplomatic, pointing to readings and class discussions to help students use Johnson (2005) and CRT. I have read about racist remarks and actions of other faculty and administrators in student journals, and this makes me very uncomfortable in certain situations. Students have also shared childhood experiences of extreme poverty, mental health issues in the family, and racist teachers. Just about every year I say this is the last time I will teach this course because the emotional stress for the instructor can be immense (Brayboy 2003; Smith et al. 2011). Diversity instructors also run the risk of poor course evaluations because becoming aware of diversity and social injustice is not a comfortable thing for many students (Rodriguez 2009).

Smith et al. (2011) refer to the constant racial microaggressions as "mundane, extreme environmental stress" (p. 64) that leads to racial battle fatigue in Black males. The authors found that the higher the education level in their study population, the higher the stress experienced. Black males are constantly under surveillance, stereotyped, and experience blatant racism that can result in real health issues such as high blood pressure. While my experience is not as extreme, because I model the behavior I expect from students, and because I am the only Native American on the school of education faculty and only one of two at my institution, I am under the constant gaze of my students and colleagues. I am aware that students are watching how I react to guest speakers, events on campus, and the actions of my colleagues. I know because some of my reactions and comments have been noted in the student journals. One student even recorded my body language during class.

Brayboy (2003) has noted that institutions, despite claims of meritocracy and colorblind policies, place the burden of diversifying the institution, literally, on faculty of color. Faculty of color, by and large, teach diversity courses; the issue of 
"other" becomes the responsibility of the "other" (p. 76). He calls this a "hidden service" of faculty of color, most of whom are untenured. He acknowledges that many of us genuinely want to teach these courses but the problem is when it is expected simply because we are faculty of color.

Rodriguez (2009) investigates teacher authority when teacher is "other" especially in a diversity-based course. The "dynamics" of gender and race complicate authority for women of color (p. 485), and when combined with a diversity course, a course that some students find unnecessary or intimidating, authority can be challenged. Rodriquez relates how some students felt free to criticize the existence of the course, and even left after she asked them to stay to discuss a project. Rodriguez shares that a colleague of color had a student verbally challenge the instructor throughout the course while sitting in a sexually aggressive manner. While that has not happened to me, I did have a student refuse to face the class, keeping her chair at angle so she did not have to make eye contact. I insisted, and she would begin the class facing classmates, but by the end of the class, her desk would be turned away from her classmates.

In addition to the above, some students are reluctant to share personal experiences. Students do not have to share anything they are uncomfortable sharing. They can still do all the assignments without sharing personal experiences. The few students who have been uncomfortable sharing personal experiences have shared powerful stories about their work experiences. One student who had a difficult childhood wrote her self-description in the third person. To date this has been the only self-description to bring me to tears.

While Johnson (2005) does include ability status in his discussion of "isms," I have struggled to adequately incorporate abilities into the discussion. Handicap building access is discussed, often initiated by the class, but I have not figured out how to incorporate ability in a meaningful way. The semester is short, and I have been challenged to find resources related to higher education and ability status, and I struggle as do many faculty with being able to address an issue adequately, when I only have one semester to do so. What topics do I cover? How in depth can we go? Do I cover several issues broadly or concentrate on one or two? I acknowledge that this is not an adequate reason for not incorporating ability status into the course.

\section{Recommendations}

This course should be two semesters. There are films that I have had to remove and there are events we cannot attend because there are not enough weeks in the semester. A part two would allow the class to expand their analysis because more readings, personal experiences, films, and counterstories could be explored. Also, investing in a longer diversity course would convey the importance and the institution's commitment to diversity.

An academic year course would also allow the class the time to dig deeper into issues of social justice. After the theoretical foundation, the class could explore issues of power and control (Foucault 1995) more deeply and take the course in 
more personal directions. For example, I have been surprised at what mental illness has done to families; something rarely explored in our classes. We could also incorporate more activities. One activity I have never been able to incorporate is to have the class ride public transportation, ideally for one week. The privilege of owning a reliable vehicle, of not being reliant on a transit schedule, and having the choice of whether or not to ride public transportation, is a privilege many students are not aware they have. Using a vehicle, often at significant financial and environmental cost, has become a social class norm.

I imagine that most instructors would say they incorporate diversity into their courses. Many students have indicated otherwise in their journals. That is not to say diversity is not evident in their coursework. I provide tools to "see" the diversity. Still, I think a diversity assessment of our curriculums is a worthwhile exercise. I also think faculty are not particularly well trained in discussing diversity issues, and it would be an investment in our faculty to engage in professional development not only for diversity but teaching skills. And because so many education faculty emphasize a commitment to social justice, having the faculty write a social justice statement would bring social justice issues to the forefront.

Each instructor has a distinct way of approaching diversity. We can all learn from these different approaches. I know I have incorporated exercises and readings from other instructors, and I learn from my students every semester. The majority of the students I have taught are White with diverse experiences that are typically not visible: extreme childhood poverty, mental illness, different faiths, and domestic violence. Students have offered up ways to challenge the path of least resistance that have made me proud, and made us laugh. One student, on his own, spent the day in a wheel chair, taking notes of his experience, and wrote a report that he presented to our university president.

Because this course is only one semester, I can only hope the lessons learned have taken hold and that the students go on to challenge the status quo, continue to exercise the new lens, and "resist the paths of least resistance" (Johnson 2005, p. 80). Anecdotally, students from the past have told me they understand why I assigned Tate (1997) now, a year or two after they took the course. And I have had a few former students email me about some social justice projects they are engaged in.

\section{Conclusion}

I take to heart Anzaldúa's (1990) words that we find practical applications for our theories. In this article I discussed the use of Johnson (2005) and Critical Race Theory in a course on diversity in higher education. Johnson exposes the system of privilege that we all participate in through paths of least resistance. CRT was introduced as a tool to let students tell it like it is. My philosophy regarding the course, and then examples of using CRT were provided. I feel that CRT expands our discussion of diversity because of the assumption that racism is everywhere. The CRT analysis tool developed by a former class was described and example 
shared from a student's content analysis paper. Challenges were discussed and recommendations were made. I hope some readers can use this format as a stepping off point as they develop or revise their own courses. This is not the only way to engage students in a diversity course. I offer my thoughts in hopes that we can discuss, build, and improve our courses, and disrupt our own paths of least resistance.

\section{Appendix 1}

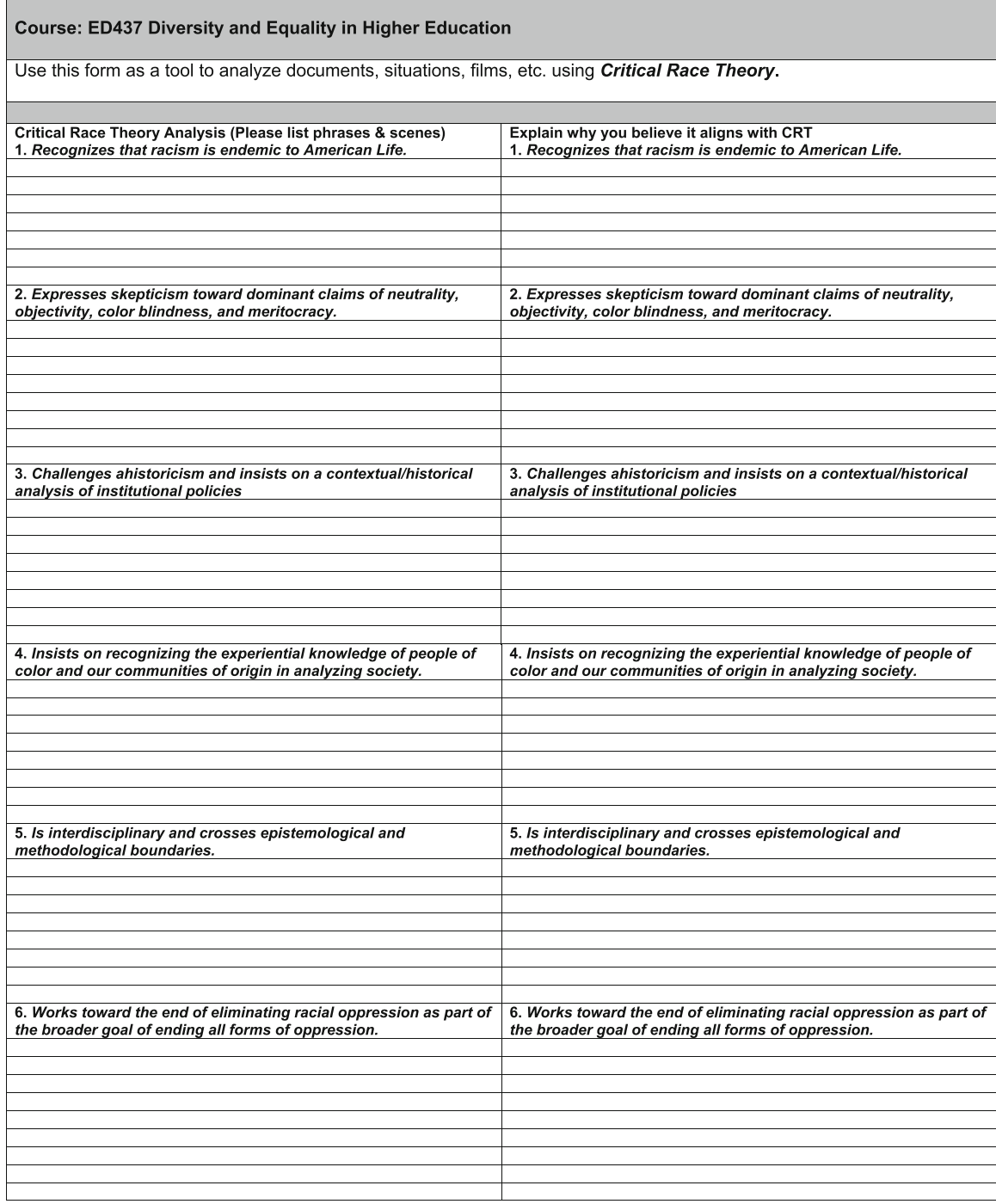




\section{Appendix 2}

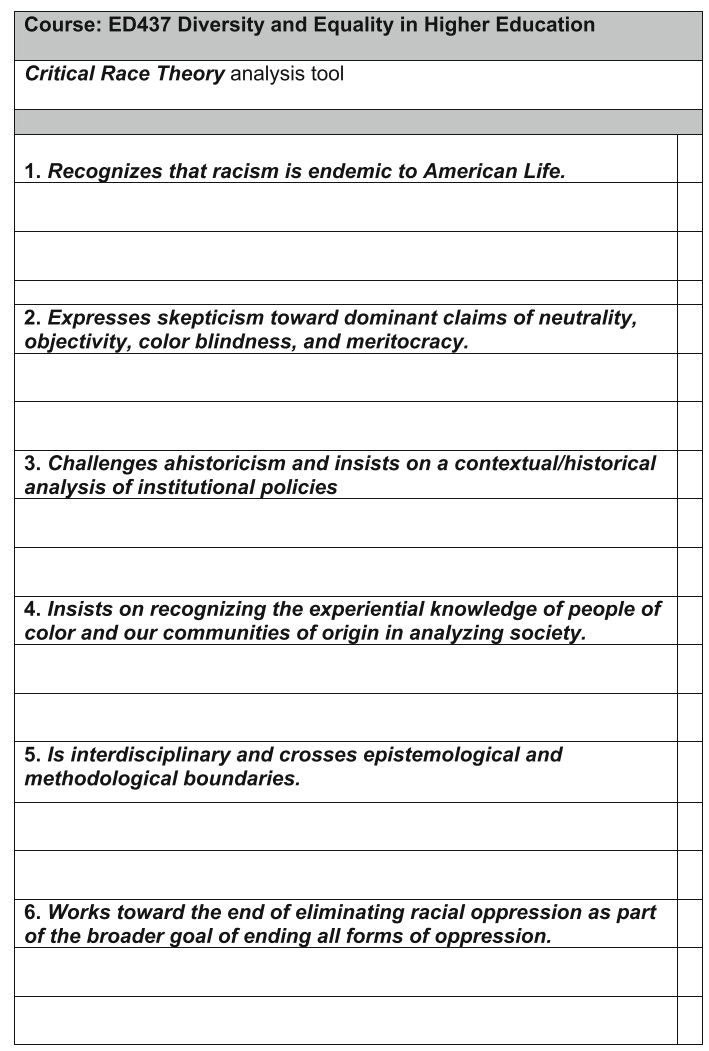

\section{References}

Anzaldúa, G. (1990). Haciendo Caras/making face, making soul: Creative and critical perspectives by women of color. San Francisco, CA: Aunt Lute Press.

Aud, S., Hussar, W., Kena, G., Bianco, K., Frohlich, L., Kemp, J., et al. (2011). The condition of education 2011 (NCES 2011-033). Washington, DC: U.S. Department of Education, National Center for Education Statistics.

Banks, C. A. (2009). Black women undergraduates, cultural capital, and college success. New York, NY: Peter Lang.

Banks, J. A., \& Banks, C. A. M. (2001). Handbook of research on multicultural education. San Francisco, CA: Jossey-Bass.

Bell, D. (1987). And we are not saved: The elusive quest for racial justice. New York, NY: Basic Books. Bensimon, E. M. (Ed.). (1994). Multicultural teaching and learning. University Park, PA: NCTLA.

Bogdan, R. C., \& Biklen, S. K. (2007). Qualitative research for education: An introduction to theories and methods (5th ed.). Boston, MA: Pearson/Allyn and Bacon.

Bonilla-Silva, E. (2003). Racism without racists: Color-blind racism and the persistence of racial inequality in the United States. Lanham, MD: Rowman \& Littlefield.

Brayboy, B. M. (2003). The Implementation of diversity in predominantly White colleges and universities. Journal of Black Studies, 34(1), 72-86. 
Cleary, L. M., \& Peacock, T. (1997). Disseminating American Indian educational research through stories: A case against academic discourse. Journal of American Indian Education, 37, 7-15. Retrieved from http://jaie.asu.edu/v37/V37S1dis.htm.

Collins, P. H. (1995). The social construction of Black feminist thought. In C. Turner, M. Garcia, A. Nora, \& L. I. Rendón (Eds.), Racial and ethnic diversity in higher education (pp. 115-133). Needham, MA: Simon \& Schuster.

Crenshaw, K. (1988). Race, reform, and retrenchment: Transformation and legitimation in antidiscrimination law. Harvard Law Review, 101(7), 1331-1387.

DeCuir, J. T., \& Dixson, A. (2004). "So when it comes out, they aren't that surprised that it is there": Using critical race theory as a tool of analysis of race and racism in education. Educational Researcher, 33, 26-31.

Foucault, M. (1995). Discipline and punish: The birth of the prison (A. Sheridan, Trans.). New York, NY: Vintage Books.

Fox, M. J. T., Lowe, S. C., \& McClellan, G. S. (Eds.). (2005). Serving Native American Students. New Directions for Student Services. San Francisco, CA: Jossey-Bass.

Grant, C. A., \& Tate, W. F. (2001). Multicultural education through the lens of the multicultural education research literature. In J. A. Banks \& C. A. M. Banks (Eds.), Handbook of research on multicultural education (pp. 145-166). San Francisco, CA: Jossey-Bass.

Harper, S. R., \& Patton, L. D. (2007). Responding to the realities of race on campus. New Directions for Student Services, 88. San Francisco, CA: Jossey-Bass.

Howard, T. (2003). Culturally relevant pedagogy: Ingredients for critical teacher reflection. Theory into Practice, 42(3), 195-202.

Johnson, A. G. (2005). Privilege, power, and difference (2nd ed.). New York, NY: McGraw Hill.

Kumashiro, K. K. (2000). Toward a theory of anti-oppressive education. Review of Educational Research, 70(1), 25-53. doi:10.3102/00346543070001025.

Ladson-Billings, G. (1995). But that's just good teaching! The case for culturally relevant pedagogy. Theory into Practice, 34, 159-165.

Ladson-Billings, G. (1998). Just what is critical race theory and what's it doing in a nice field like education? Qualitative Studies in Education, 11(1), 7-24.

Love, P., \& Guthrie, V. (1999). Perry's intellectual scheme. New Directions for Student Services, 88, 5-15.

Martinez, G. (2006). "In my history classes they always turn things around, the opposite way": Indigenous youth opposition to cultural domination in an urban high school. In M. W. Apple \& K. L. Buras (Eds.), The sublatern speak: Curriculum, power, and educational struggles (pp. 121-140). New York, NY: Routledge.

McEwen, M. K., Kodama, C. M., Alvarez, A. N., Lee, S., \& Liang, C. T. H. (Eds.). (2002). Working with Asian American College Students. New Directions for Student Services. No. 97, San Francisco, CA: Jossey-Bass.

Rhoads, R. A. (1995). Critical multiculturalism, border knowledge, and the canon: Implications for general education and the academy. JGE: The Journal of General Education, 44(4), 256-273.

Rhoads, R. A. (1998). Critical multiculturalism and service learning. New directions for teaching and learning, 73(Spring), 39-46.

Rodriguez, D. (2009). The usual suspect: Negotiating White student resistance and teacher authority in a predominantly White classroom. Cultural Studies/Critical Methodologies, 9(4), 483-508. doi: $10.1177 / 1532708608321504$.

Sanlo, R. (Ed.). (2005). Gender identity and sexual orientation: Research policy, and personal perspectives. New Directions for Student Services, No. 111. San Francisco, CA: Jossey-Bass.

Sleeter, C. E. (1993). Multicultural education: Five views. The Education Digest, 58(7), 53-57.

Smith, W. A., Hung, M., \& Franklin, J. D. (2011). Racial battle fatigue and the miseducation of Black men: Racial microaggressions, societal problems, and environmental stress. The Journal of Negro Education, 80(1), 63-82.

Tate, W. F., I. V. (1997). Critical race theory and education: History, theory, and implications. Review of Research in Education, 22, 195-247.

Vygotsky, L. S. (1986). Thought and language (A. Kozulin, Trans.) Cambridge, MA: MIT Press.

Yosso, T. J. (2006). Critical race counterstories along the Chicana/Chicano educational pipeline. New York, NY: Peter Lang.

Yosso, T. J., Smith, W. A., Ceja, M., \& Solorzano, D. G. (2009). Critical race theory, racial microaggressions, and campus racial climate for Latina/o undergraduates. Harvard Educational Review, 79(4), 659-786. 